\title{
INDUCTION MOTOR DIAGNOSIS WITH USE OF ELECTRIC PARAMETERS
}

\author{
Krzysztof ROCZEK, Tomasz ROGALA \\ Institute of Fundamentals of Machinery Design, Faculty of Mechanical Engineering, \\ Silesian University of Technology, \\ krzysztof.roczek@opel-vauxhall.com, tomasz.rogala@polsl.pl
}

\begin{abstract}
Induction motors are very commonly used in industry. From that reason more and more often different methods of induction motor diagnosis are applied. In this article motor current signature analysis (MCSA) method is presented with special Extended Park's Vectors Approach. This method extends the possibility of current signals analysis in frequency domain giving better recognition of some faults. In the presented experiment few malfunctions were applied to the laboratory stand which consists of two different induction motors. In both cases they were supplied from frequency inverter, therefore additionally influence of this type of control on current spectrum is presented. The results of presented research and gathered experience in this domain are the basis for the elaboration of advanced on-line diagnostic system for industrial object.
\end{abstract}

Keywords: induction motor, MCSA, current spectrum, frequency inverter

\section{DIAGNOSTYKA SILNIKA INDUKCYJNEGO Z WYKORZYSTANIEM PARAMETRÓW ELEKTRYCZNYCH}

\section{Streszczenie}

Silniki indukcyjne są powszechnie używane w przemyśle. $\mathrm{Z}$ tego powodu coraz częściej stosowane są różne metody ich diagnozowania. W niniejszym artykule zostały zeprezentowane metody MCSA z wykorzystaniem zastosowania podejścia EPVA (Extended Park's Vector Approach). Metoda ta daje bardzo dobre możliwości diagnostyczne przy wzroście czułości systemu oraz jego niezawodności. W opisanym poniżej doświadczeniu zaimplementowano do układu kilka uszkodzeń. System składał się z dwóch typów silników, które były zasilone i sterowane za pomocą przemiennika częstotliwości. W doświadczeniu wyeksponowano również wpływ przemiennika częstotliwości na widmo prądowe silnika. Przedstawione wyniki badań i zdobyte $\mathrm{w}$ trakcie ich wykonywania doświadczenie stanowią podstawę do opracowania systemu diagnostycznego działającego w czasie rzeczywistym dla obiektu przemysłowego.

Słowa kluczowe: silnik indukcyjny, MCSA, widmo prądu, przemiennik częstotliwości

\section{INTRODUCTION}

Induction motors are one of the most commonly used machines in all branches of industry. Of course one may find also very often synchronous machines, DC drives and servodrives, but asynchronous machines are the core of many applications and, in consequence, may become a source of problems and production line stoppages. The complete research was performed to verify the response of diagnostic system that analyses the induction motor supplied from frequency inverter. Similar application is installed on a stamping press line that will be analyzed in the next step of author's activity.

Induction motors are utilized to supply pumps, aggregates, conveyors, lifters and many other equipment. Main feature of induction machines is high efficiency and low complexity. In spite of that, unexpected motor breakdowns may cause a serious financial consequences for company. For that reason within last years a lot of diagnostic methods of induction motors analysis were developed. Many of them concentrate on parameters like vibrations [21], temperature [22] or noise [23], but it is also easy to find descriptions of methods that use analysis of electric current [1, 2, 4, 5].

Successive paragraphs will describe briefly some available methods of induction motors diagnosis and results of research performed.

The second section contains information about the basic methods of technical state assessment of induction motors. The third section refers to more advanced analysis Motor Current Signature Analysis MCSA. Next section describes conducted research on the basis of laboratory stand with the use of two different induction motors.

\section{MOTOR BASIC PARAMETERS ANALYSIS}

Apart of all methods that ensure online diagnosis the procedure that is most commonly 


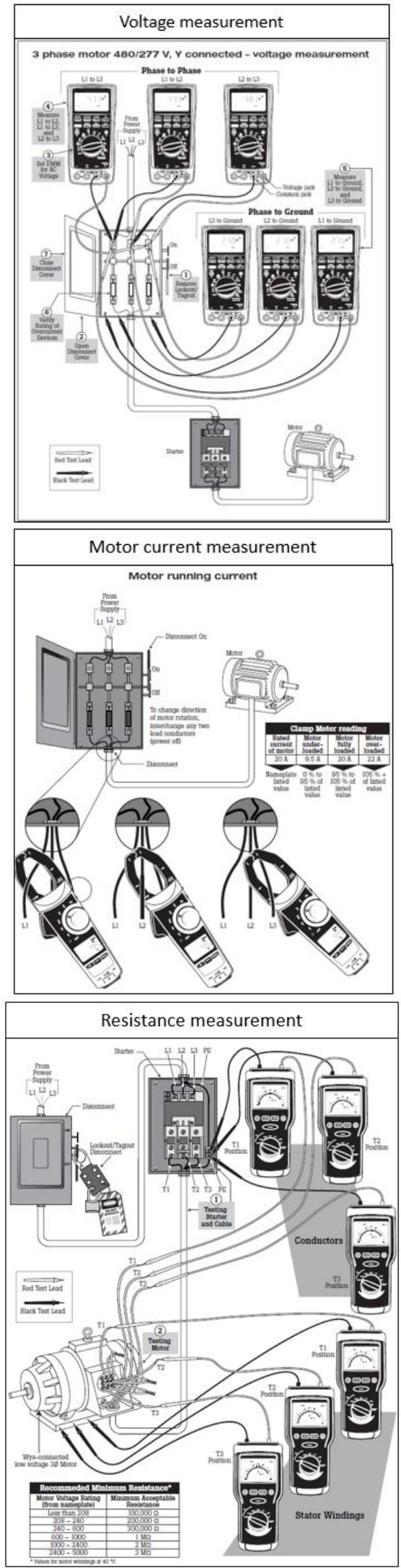

Fig. 1. Motor basic parameters measurement [2]

done by maintenance in industry is control and analysis of basic motor parameters, such as voltage between phases, voltage-ground, motor current, resistance measurement. This kind of measurements should be done regularly, according to prepared schedule. Tools used for that purpose are simple multimeters but also current meters and inductor insulation meters. Figure 1. presents basic methods of induction motor diagnosis. One may notice here voltage measurements. It is very important to check this parameter periodically. Asymmetric supply voltage will have negative influence. Unbalanced power supply causes that the loss characteristic becomes much more complex and the efficiency of induction motor decreases significantly. Voltage unbalance means that three voltage vectors have different magnitudes or the phase angle between them is not equal to 120 degrees [3].

Analysis of this parameter requires use of more sophisticated than just simple multimeter. However, if there is no special tool available, regular measurement of input voltage will also be valuable. Another parameter that should be verified regularly is motor current. Each phase of induction drive should be loaded equally. Unbalance of motor current is a first symptom of need for making further investigation. Similar situation is related to the resistance measurement. It is necessary to disconnect induction motor from its power supply to perform this kind of measurement. It may show any isolation damages that may occur on windings. It is necessary to make those measurements regularly to have reference data related to the status of the machine [15]. Otherwise it is more difficult to say what the current state of motor is.

Author in [20] shows practical approach of electrical machines diagnosis. Author describes in details different methods of motors analysis: windings resistance, windings induction, voltage insulation tests, partial discharge, tan alpha as well as thermal tests.

A very helpful for machinery diagnosis is use for that purpose knowledge contained in norms and standards. One of the norm that describes set of methods based on stator current measurement is ISO 20958. One may find here detailed description of Motor Current Signature Analysis with explanation of formulas that defines possible motor faults, i.e.: broken rotor bar, short circuit, eccentricity. Norm presents also Park's vector approach, which is advanced method of faults identification.

There are many tools available in the market that allow to perform basic motor check, but it is also possible to use deeper current analysis to receive higher accuracy and system reliability.

\section{MOTOR CURRENT SIGNATURE ANALYSIS}

Motor Current Signature Analysis (abb. MCSA) is the method that can be successfully applied to both squirrel cage and wound motors. Figure 2 presents the place of MCSA among other electrical methods of malfunctions and fault isolation. There are huge advantages of MCSA. 


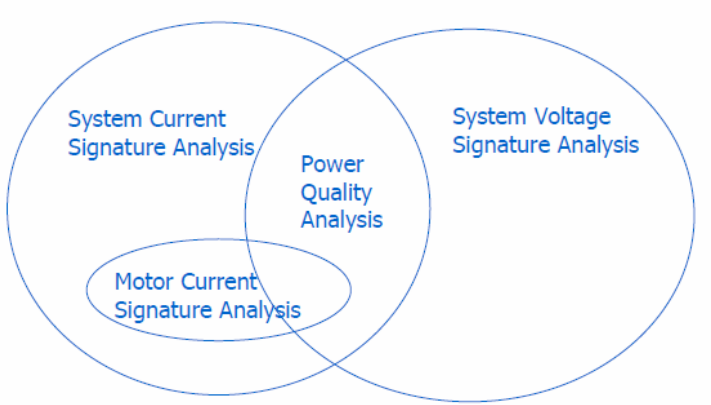

Fig. 2. Electrical methods of motor diagnosis

Generally these methods are not so expensive in relation to vibration based method. One of the method that is a part of MCSA is spectral analysis of induction motor power supply current. The next step of analysis is calculation of frequencies characteristic for particular malfunction. One may find below basic drives malfunctions and their symptoms in electric current.

\subsection{Eccentricity}

Figure 3 explains concentricity of rotor shaft and two types eccentricity: static and dynamic one [6]. Static eccentricity is a state which is determined as an unequal distance between rotor and stator is not equal for each place of rotor, but it does not change during rotation. In case of dynamic eccentricity the distance between stator and rotor changes during rotation.

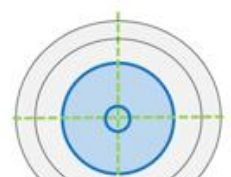

a)

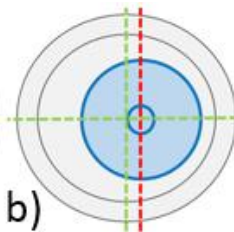

c)

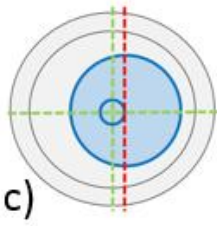

Fig. 3. Concentricity and types of eccentricity:

a) concentricity, b) static eccentricity, c) dynamic eccentricity

The below formula presents spectrum frequencies that appears in a moment of eccentricity appearance [10].

$$
f_{e c}=f_{g}\left\{R\left(\frac{1-s}{p}\right) \pm n_{w s}\right\} \pm\left(\frac{1-s}{p}\right)
$$

where: $f_{e c}$ - is the eccentricity frequency, $f_{g}$ power supply frequency, $\mathrm{R}-$ number of rotor bars in squirrel cage, $\mathrm{s}-$ slip, $\mathrm{k}=1,2,3 . ., \mathrm{n}=1,2, .$. , are integer numbers, $\mathrm{p}-$ number of poles, $\mathrm{n}_{\mathrm{d}}= \pm 1$, $\mathrm{n}_{\mathrm{ws}}=1,3,5,7 \ldots$

\subsection{Broken rotor bar}

This parameter can be evaluated from the following equation[10]:

$$
f_{b r b}=f_{g}\{1 \pm 2 k s\}
$$

where: $f_{g^{-}}$power supply frequency, $k=1,2,3$, $\mathrm{s}-\operatorname{slip} \mathrm{p}-$ number of poles.
In case of broken rotor bar frequencies defines by equation (2) may appear in the frequency spectrum.

\subsection{Short circuit of stator windings}

Short circuit is very common malfunction of induction motors. Equation 3 presents the equation that defines characteristic frequency of stator windings short circuit [10]:

$$
f_{s t}=f_{g}\left\{\frac{n}{p}(1-s) \pm k\right\}
$$

where: $f_{g}$ - power supply frequency $s-\operatorname{slip} k=1,2$, $3, \ldots \mathrm{n}=1,2,3, \ldots \mathrm{p}$ - number of poles.

\subsection{Unbalanced load (variable torque)}

Equation 4 allows to calculate characteristic frequency of variable torque [10].

$$
f_{\text {load }}=f_{g} \pm m f_{r}=f_{g}\left[1 \pm m\left(\frac{1-s}{p}\right)\right]
$$

where $f_{g}$ - power supply frequency, $m=1,2,3, \ldots$ $f_{r}$ - rotation frequency, $s-$ slip, $p$-number of poles

\subsection{Broken bearing}

This kind of problem appears very often in applications where concentricity issue also occurs. Practice shows that it is better to identify this malfunction with the use of accelerometers and vibrations measurement. This method has better sensitivity than MCSA. In spite of that it is also possible to find symptoms of broken bearing in electric current spectrum [23]. It is necessary to use for that purpose the following equation (Eq. 6) [10]:

$$
f_{0}=0,4 n_{b} f_{r m} \quad f_{1}=0,6 n_{b} f_{r m}
$$

$$
A=20 \cdot \log \left(\frac{A_{f_{0}}}{A_{f_{1}}}\right)[d B]
$$

where $n_{b^{-}}$number of balls in the bearing, $f_{r^{-}}$ rotation frequency, $\mathrm{A}_{\mathrm{f} 0}, \mathrm{~A}_{\mathrm{f} 1^{-}}$amplitudes of $\mathrm{f}_{0}$ and $\mathrm{f}_{1}$ frequency components.

Having the indicator $A$ it is necessary to check its value which directly defines condition of motor bearings. According to paper [11] the following values may be the qualitative evaluation of the technical state (condition) of the rotor bearings.

Table 1. Technical condition of motor on basis of A coefficient [11]

\begin{tabular}{|l|l|}
\hline $\begin{array}{c}\text { Value of A } \\
\text { indicator }[\mathrm{dB}]\end{array}$ & \multicolumn{1}{c|}{ Technical condition } \\
\hline $54-60$ & Very good \\
\hline $48-54$ & Good \\
\hline $42-48$ & Moderate \\
\hline $36-42$ & Bad: broken rotor bars or rings \\
\hline $30-36$ & $\begin{array}{l}\text { Very bad: Wide range of damages } \\
\text { in the motor }\end{array}$ \\
\hline$<30$ & Critical: Serious motor damage \\
\hline
\end{tabular}




\section{EXPERIMENT DESCRIPTION}

The purpose of the experiment was to validate the diagnostic system and implemented methods of signal analysis that are under preparation for industrial application. An experiment was carried out with the use of among others, parameters mentioned in section 3 . The same or very similar methodology will be applied in diagnostic system of a main drive of stamping press. The purpose of the experiment was also to check applied algorithms of MCSA for simulated malfunctions. The defects applied to the motor are the result of criticality analysis performed for main drive of stamping press:

- $\quad$ eccentricity (misalignment);

- motor overload;

- $\quad$ damaged bearing on drive side;

- $\quad$ damaged outer ring on non-drive side;

- unbalanced load

One may notice here that MCSA methods are well described in many papers as well as norms. Nevertheless, it was necessary to perform a laboratory check of implemented algorithms to be sure that it will be possible to detect similar problems in industry. During experiment two types of motors were tested. In both malfunctions were intentionally applied and MCSA was performed.

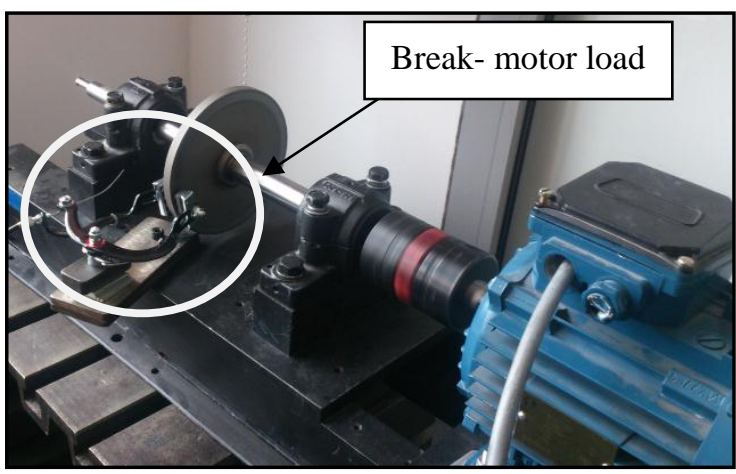

Fig. 4. Laboratory stand 1

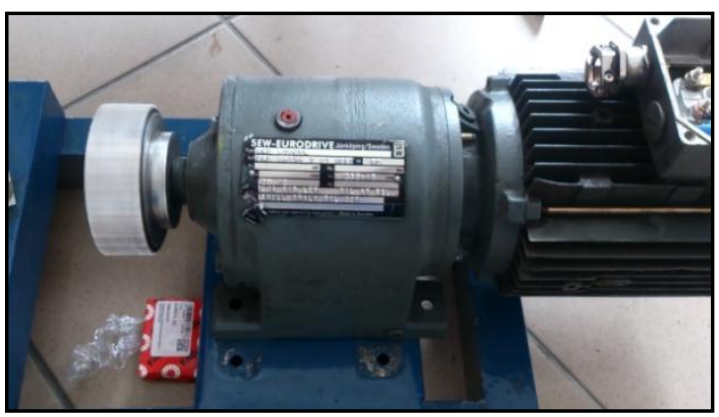

Fig. 5. Laboratory stand 2

Figures 4 and 5 present motors that were tested during complete laboratory experiment. Figures 6 and 7 presents also measurements system, which will be also in use in industry- National Instruments
RIO and Allen Bradley controller (Logix55LSP). During the experiment the current transducers (LEM HAS 50-S) were applied to measure input current of three phase motors. The motors were supplied from frequency inverter Sinamics V20 V20 230V/400V, 3kW. The measurement data were read by National Instruments RIO module and stored on external flash memory. Additionally, during experiment PLC was configured. Data transmission was established with the use of DeviceNet interface due to the fact that it is planned to startup this diagnosis system on a real industrial object with Allen Bradley controller.

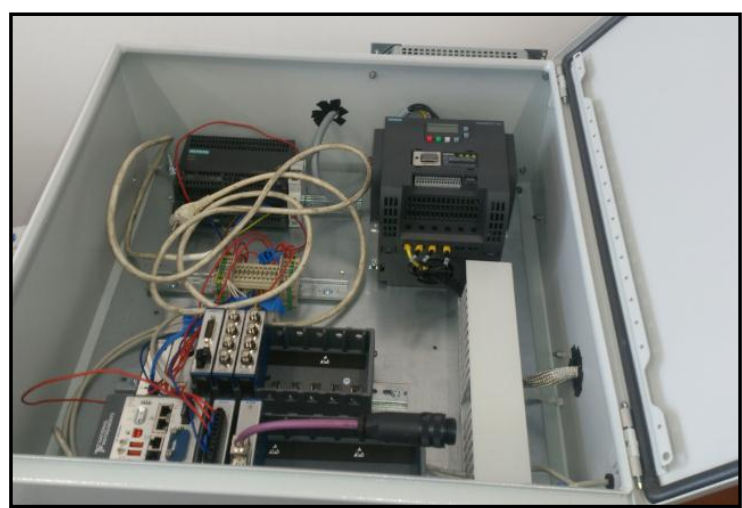

Fig. 6. Measurement system with frequency inverter

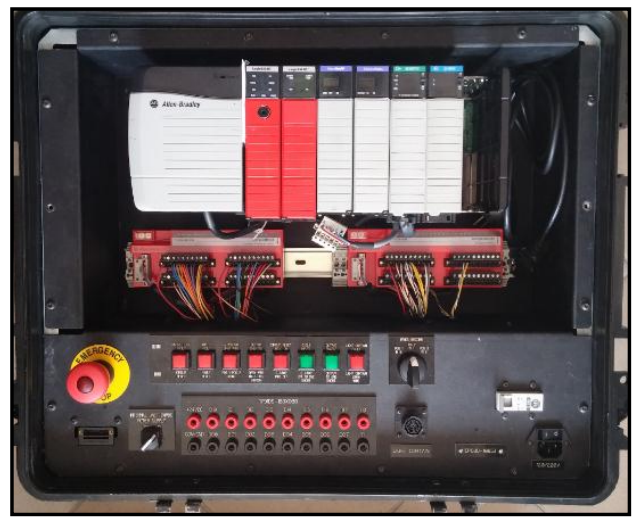

Fig. 7. Box with Allen Bradley PLC

The power supply for RIO modules is taken from Siemens SITOP 5A module. Due to the fact that symmetrical power source was unavailable during experiment, the voltage divider was built with use of resistors. Thanks to that, the neutral point was defined as well as positive and negative voltage. This kind of power supply was required by LEM current transducers [15].

Additionally, it was verified whether additional resistance will have a negative influence on the symptoms levels or frequency response of the system.

Figure 8 presents the simplified scheme of complete measurement stand. 


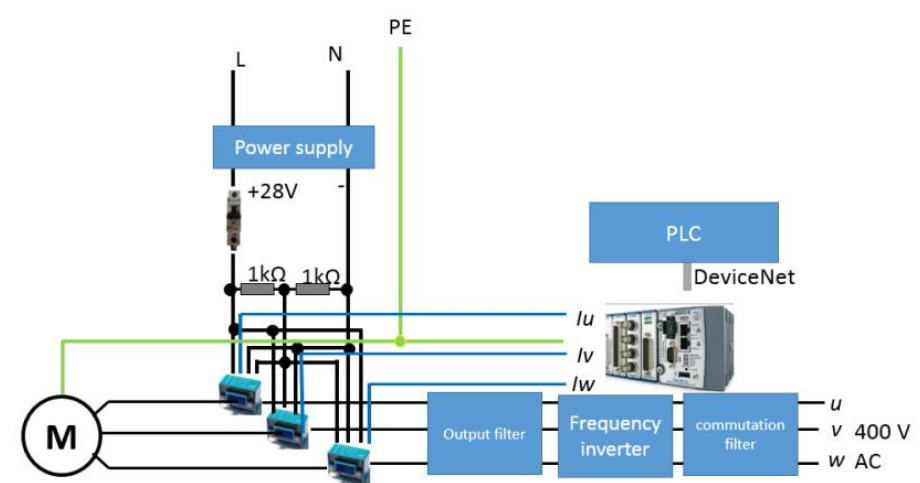

Fig. 8. Measurement stand- diagram

During the experiment two types of drives were analyzed. Tables 2 and 3 present basic parameters of motors that were tested.

Table 2. Motor 1- basic parameters

\begin{tabular}{|r|r|r|}
\hline Motor Inducta SH90S-2 & & \\
\hline Power & 1,5 & $\mathrm{~kW}$ \\
\hline Nominal speed & 2835 & $\mathrm{Rpm}$ \\
\hline Pairs of poles & 1 & \\
\hline Bearing of drive side & $62052 \mathrm{Z}$ & \\
\hline Slip & 0,055 & \\
\hline Basic supply fr & 8 & $\mathrm{~Hz}$ \\
\hline Speed during test & 567 & $\mathrm{Rpm}$ \\
\hline Nominal current & 3,4 & $\mathrm{~A}$ \\
\hline
\end{tabular}

Table 3. Motor 2- basic parameters

\begin{tabular}{|r|r|r|}
\hline Motor SEW DT80K4 & & \\
\hline Power & 0,55 & $\mathrm{~kW}$ \\
\hline Nominal speed & 1350 & $\mathrm{Rpm}$ \\
\hline Pairs of poles & 2 & \\
\hline Bearing of drive side & $6303 Z$ (7 balls) & \\
\hline Slip & 0,05 & \\
\hline Basic supply fr & 50 & $\mathrm{~Hz}$ \\
\hline Speed during test & 1350 & $\mathrm{Rpm}$ \\
\hline Nominal current & 1,75 & $\mathrm{~A}$ \\
\hline $\begin{array}{r}\text { Bearing of counterdrive } \\
\text { side }\end{array}$ & $6203(8$ balls $)$ & \\
\hline
\end{tabular}

The complete experiment consists of few steps during which current measurements were performed in different technical state presented in the next subsections.

\subsection{Motor 1 - healthy motor and proper alignment}

During first experiment rotation speed was set to $567 \mathrm{rpm}$ (10 Hz on frequency inverter).

Apart of before mentioned features the Total Harmonic Distortion was also calculated. It is a ratio between root mean square (rms) value of higher harmonics to the rms value of the basic one. The value was calculated on the basis of first nineteen harmonics. The formula is given in the equation 7 .

$$
T H D[\%]=\sqrt{\sum_{n=2}^{n=19}\left(\frac{Q_{n}^{2}}{Q_{1}^{2}}\right)} * 100 \%
$$

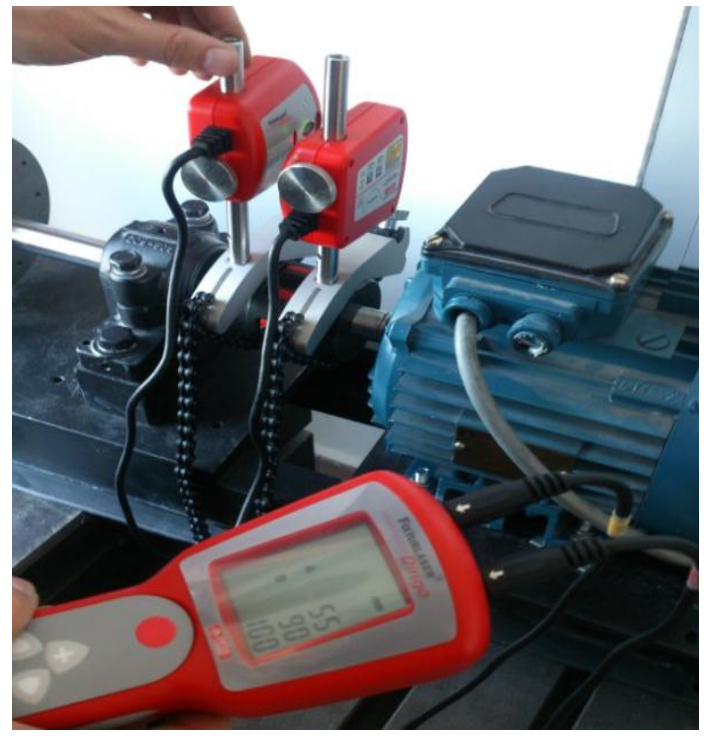

Fig. 9. Alignment adjustment with use of Dirigo Fixture Laser tool

Figure 10 presents raw current signal. During the analysis FFT method was used to identify characteristic frequencies of successive problems. Figures 11 and 12 show spectrum of electric current that supplies Inducta motor with one difference. The first spectrum is the spectrum of raw signal. In the second case, it is spectrum taken from Park's vector. The Park's vector is described by the following equation:

$$
\left|i_{s}\right|=\sqrt{i_{s \alpha}^{2}+i_{s \beta}^{2}}
$$

where

$$
i_{s \alpha}, i_{s \beta} \quad \begin{aligned}
& \text { are the components of stator } \\
& \text { current. }
\end{aligned}
$$

Spectrum of Park's vector has one, very important feature that may be used in electric machines diagnosis- the fundamental frequency is no longer dominant in complete spectrum. Thanks to that other stripes (frequency components) like malfunctions symptoms are better visible. One may see in figure 11 fundamental frequency component (about $8 \mathrm{~Hz}$ ) and its harmonics. The second harmonic that is clearly visible here is the 
symptom of short circuit in the system or problems with power supply. In normal conditions only odd harmonics should be visible (third, fifth, seventh, etc.). One see also very high amplitude of harmonic number 23. According to IEEE 519 the harmonic number 23 should be on a level of $0,6 \%$ of amplitude of basic one [19] (Fig. 12). This high amplitude may be caused by the resonance frequency of LC circuit as connection with motor coils.

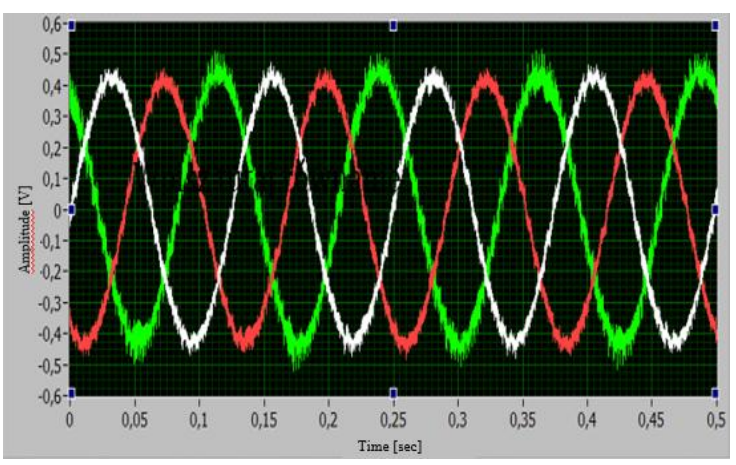

Fig. 10. Raw signals from LEM transducers of successive phases
Table 4. Characteristic frequencies for Inducta motor

\begin{tabular}{lll}
$\begin{array}{l}\text { Broken cage or windings } \\
\text { assymetry [Hz] }\end{array}$ & & \\
\hline$f_{\text {ec }}-$ excentricity $[\mathrm{Hz}]$ & 8,9 & $\mathrm{~Hz}$ \\
$f_{r b}-$ broken rotor bar $[\mathrm{Hz}]$ & 87,9 & $\mathrm{~Hz}$ \\
$f_{\text {slip }}-$ slip frequency $[\mathrm{Hz}]$ & 0,4 & $\mathrm{~Hz}$ \\
Broken bearing & & \\
$f_{0}[\mathrm{~Hz}]$ & 34,0 & $\mathrm{~Hz}$ \\
$f_{1}[\mathrm{~Hz}]$ & 51,0 & $\mathrm{~Hz}$ \\
$f_{a}[\mathrm{~Hz}]$ & 16,1 & $\mathrm{~Hz}$ \\
$f_{\text {load }}$ unbalanced load $[\mathrm{Hz}]$ & 17,5 & $\mathrm{~Hz}$ \\
$f_{k}$ supply assymetry $[\mathrm{Hz}]$ & 8,9 & $\mathrm{~Hz}$
\end{tabular}

Table 5. Harmonics amplitudes level according to IEEE

\begin{tabular}{|l|c|c|c|c|c|c|c|c|c|}
\hline $\mathrm{h}$ & 1 & 5 & 7 & 11 & 13 & 17 & 19 & 23 & 25 \\
\hline$I_{h}[\%]$ & 100 & 2,9 & 3,1 & 1,8 & 1,3 & 1,1 & 0,7 & 0,6 & 0,5 \\
\hline
\end{tabular}

Figure 12 presents also symptom of unbalanced load. It may be so due to the fact that the motor was loaded with the use of simple break (the brake was shown in Figure 4).

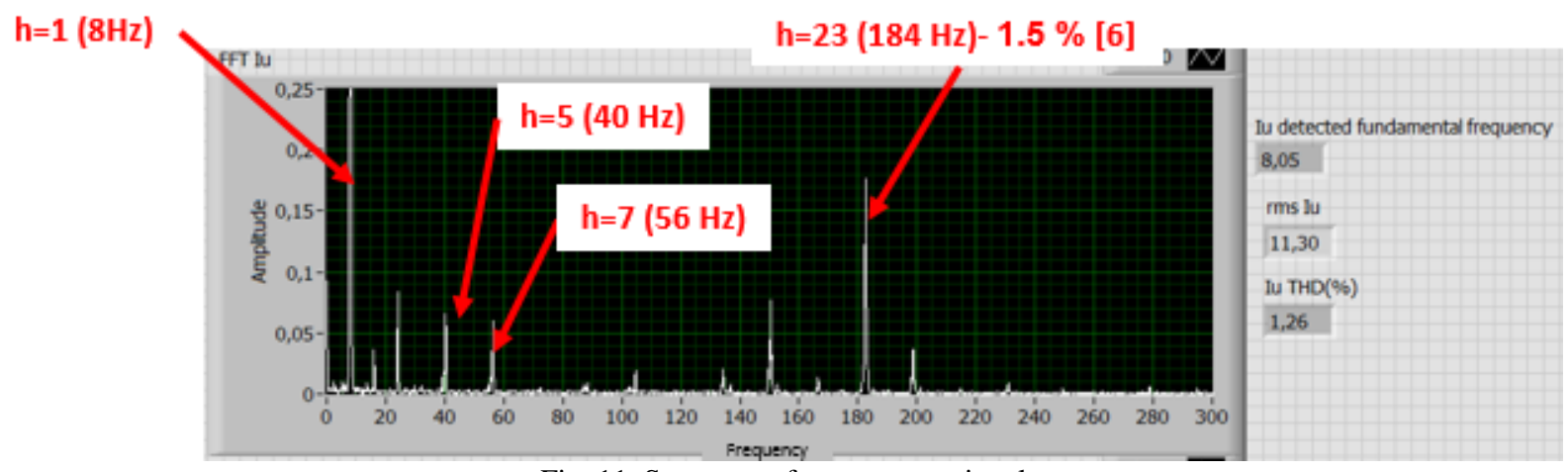

Fig. 11. Spectrum of current raw signal

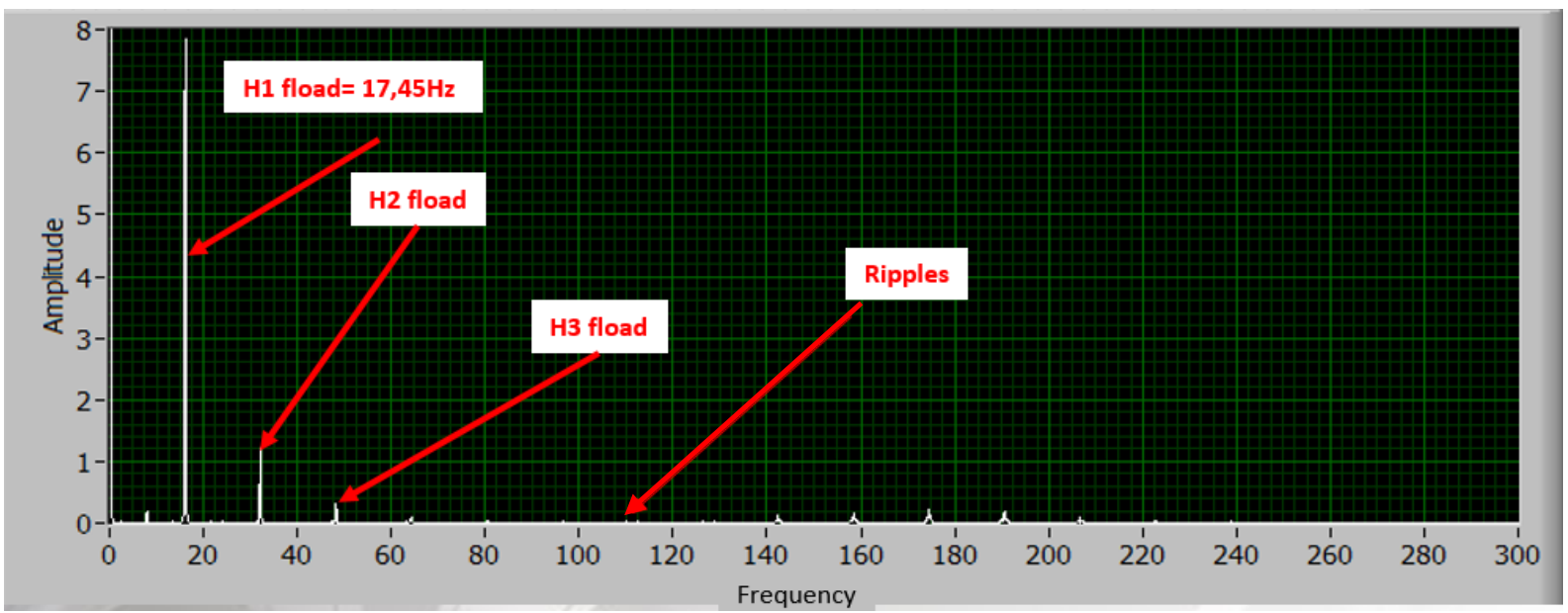

Fig. 12. Spectrum of Park's vector, where fload states as symptom of unbalanced motor load 
During the experiment an overload system was tested and its relation to sampling frequency. Sinamics frequency inverter had a pulse frequency set to $4 \mathrm{kHz}$, so it is expected to see this frequency in current frequency spectrum. Figure 13 shows that there is nothing at $4 \mathrm{kHz}$. It is caused by frequency inverter. Parameter P0290 defines behavior of Sinamics in case of overload. One of the possibility reduction of pulse frequency and in that case it was done so. One may observe that the pulse frequency was reduced to $3250 \mathrm{~Hz}$, what can be observed in current spectrum. Therefore, spectrum analysis and with respect to inverter pulse frequency is another one of the method of induction motor overload identification.

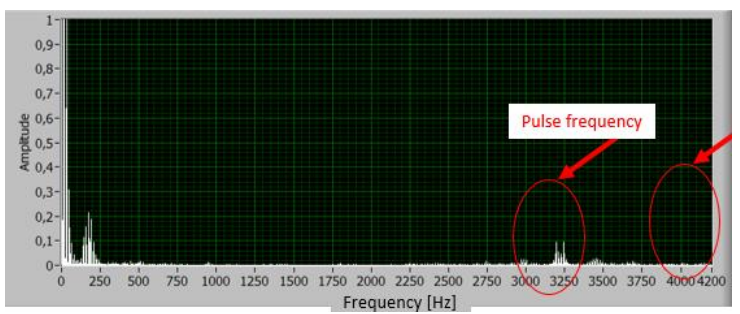

Fig.13. Pulse frequency harmonic of raw signal

Additionally, figure 14 presents the Lissajous figure of electric current after Park-Clarke transform [6]. The measures that were taken from the graph are spans in both axis.

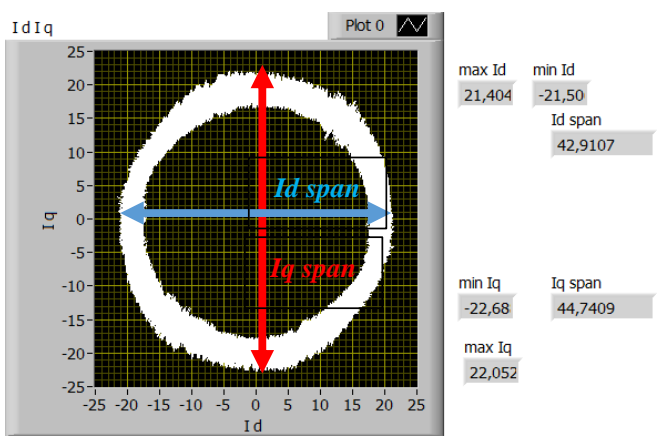

Fig. 14. Park-Clark transform- Lissajous Figure- no defect applied

\subsection{System affected by eccentricity malfunction}

Figure 15 presents eccentricity malfunction that was applied to the laboratory stand. It was done by taking out the shims from the Inducta motor.

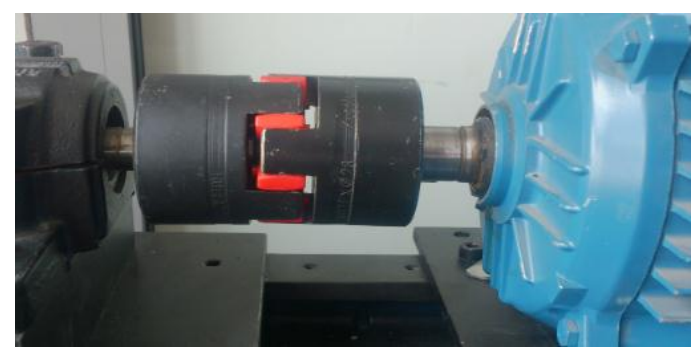

Fig. 15. Eccentricity applied to the system
Figure 16 shows that in the system still unbalanced load is present, but also one new symptom appeared- eccentricity frequency. The first component of unbalanced load is much higher that fundamental frequency of current due to the fact that spectrum was taken from Park's vector.

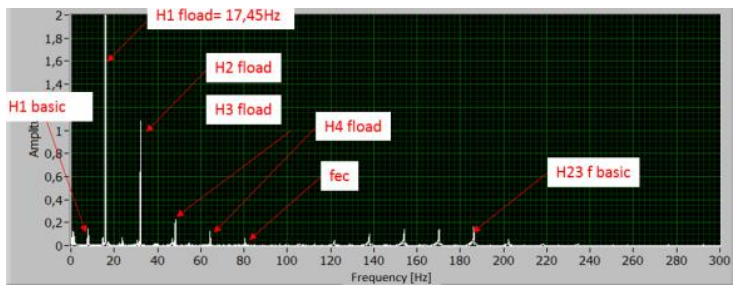

Fig. 16. EPVA Spectrum- system with eccentricity

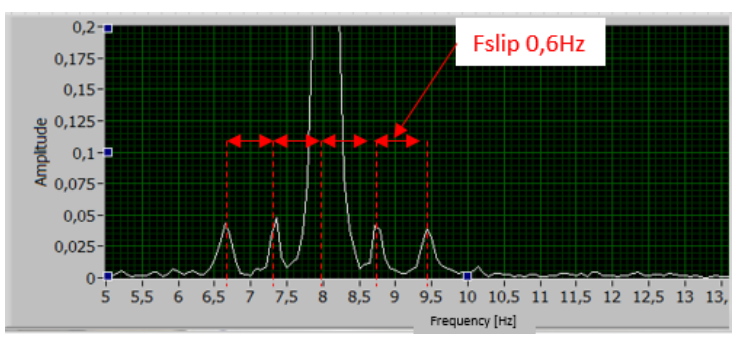

Fig.17. Slip frequency

Figure 17 shows also sidebands around fundamental frequency that are identified as slip stripes. As in the previous case, the pulse frequency was significantly reduced by frequency inverter due to high load of the system (shown if figure 18). One may recall that the nominal current of motor was on a level of $3 \mathrm{~A}$ and the measured current was nearly 4 times higher.

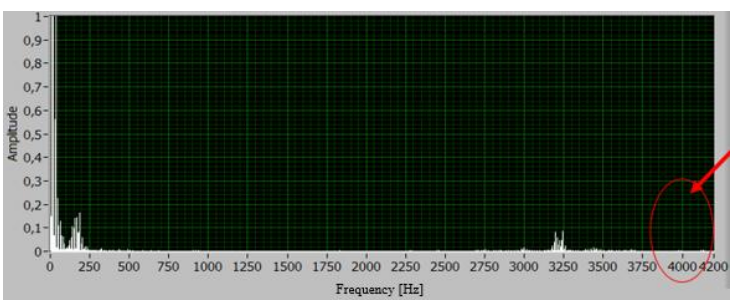

Fig. 18. Reduced pulse frequency of inverter

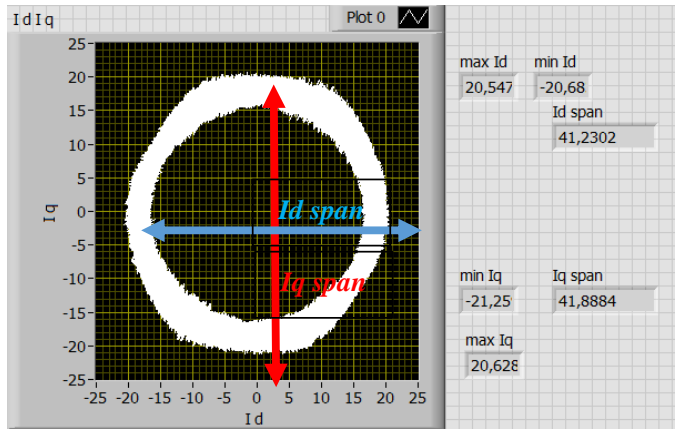

Fig. 19. Lissajous figure- eccentricity malfunction

One may see that in case of eccentricity applied to the system, the span of Lissajous figure has 
changed (shown in figure 19). The major change that may be seen is span in $I_{q}$ axis. In comparison to the healthy state, the difference may be clearly observed.

\subsection{Second motor (SEW)- no malfunction applied}

The next part of research was devoted to the analysis of SEW gear motor. At first no malfunction was applied to the system, however one may observe that the electric current signal is not so smooth as it was in the first part of analysis. It seems that there was an internal gear motor breakdown, insulation discontinuity or short circuit. The motor that was taken to the purpose of experiment was an industrial motor that work for many years in production plant. The motor was overheated a couple of times, so stator windings resistance is damaged. This may be seen in Figure 20 which presents the raw signal measured with use of LEM current transducers. One may see huge signal disturbances. During complete experiment the a output frequency (40 Hz- $1080 \mathrm{rpm})$ was set on frequency inverter Table 6 presents characteristic frequencies of SEW gear motor.

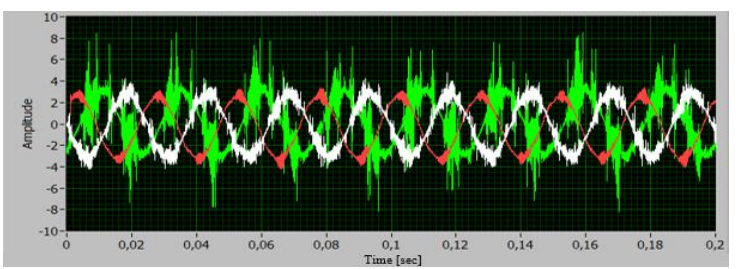

Fig. 20. Raw signal of SEW gear motor

Table 6. Calculated Characteristic frequencies of SEW

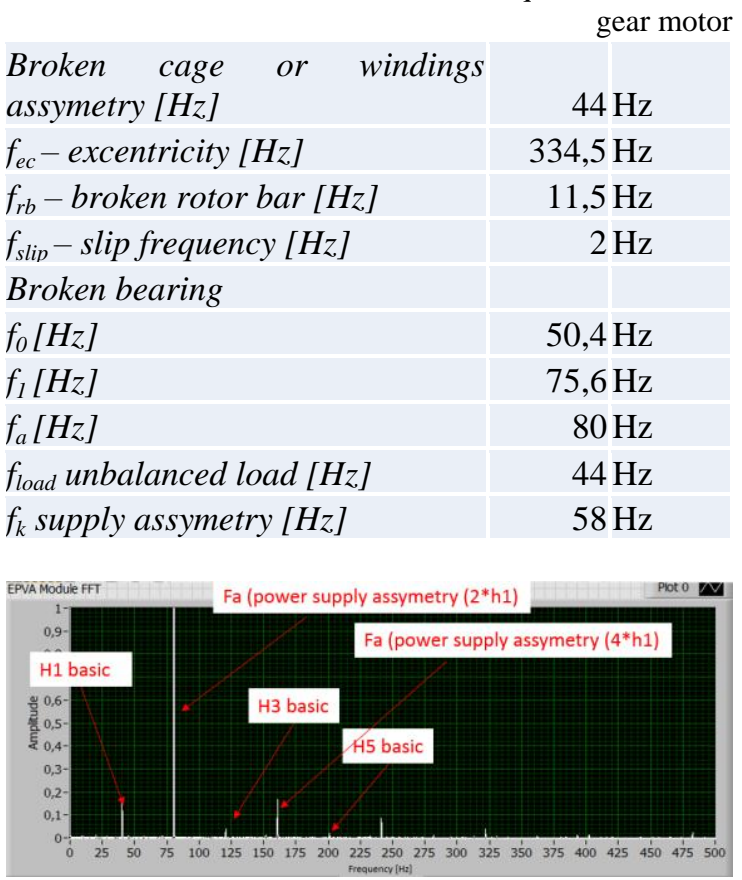

Fig. 21. Park's vector spectrum (SEW gear motor)
Figure 21 shows that there is a huge problem with power supply which results in damaged stator windings. Very high even harmonics are the proof of that as well as the shape of the raw signal. This strange behaviour of input current is also visible in Park- Clarke transform (Figure 22).

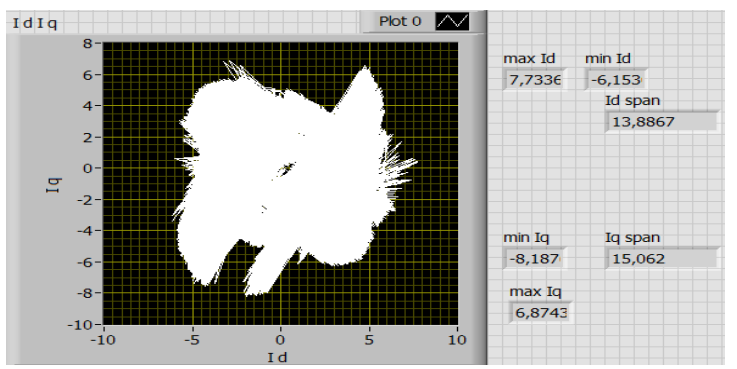

Fig. 22. Irregular shape of Lissajous figure- problem with stator windings

\subsection{Damaged outer ring of bearing 6203 (fan side)}

Another experiment was related to broken bearing of SEW gear motor. Table 7 presents basic frequencies that are characteristic for this type of bearing.

Table 7. Characteristic frequencies of 6203 bearing Bearing- fan side

6203

Number of balls

Input parameters

$\mathrm{n}_{\mathrm{i}}$ - Rotational speed of the inner ring $\quad 1080 \mathrm{r} / \mathrm{min}$

\section{Result}

$\mathrm{f}_{\mathrm{i}}$ - Rotational frequency of the inner $18,00 \mathrm{~Hz}$ ring

$\mathrm{f}_{\mathrm{e}^{-}}$Rotational frequency of the outer $0,00 \mathrm{~Hz}$ ring

$\mathrm{f}_{\mathrm{c}}$ - Rolling element set \& cage

$6,86 \mathrm{~Hz}$

$\mathrm{f}_{\mathrm{r}}$ - Rolling element about its axis

$35,80 \mathrm{~Hz}$

$\mathrm{f}_{\mathrm{ip}}$ - Point on inner ring

$89,00 \mathrm{~Hz}$

$\mathrm{f}_{\mathrm{ep}}$ - Point on outer ring

$54,90 \mathrm{~Hz}$

$\mathrm{f}_{\mathrm{rp}}$ - Rolling element

$71.7 \mathrm{~Hz}$

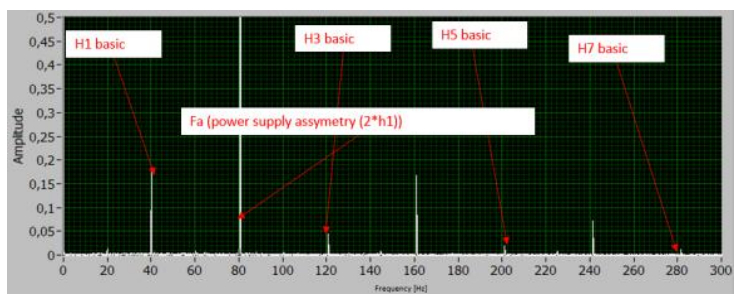

Fig. 23. Damaged outer ring of 6203 bearing in SEW gear motor

One may observe in Figure 23 that electrical problems are marked very precisely in the spectrum. Unfortunately, the characteristic frequency of bearing are invisible in the spectrum. 
It was also checked how the Lissajous figure looks like in that case. It is necessary to say power asymmetry of the system are so dominant that the round shape of Lissajous Figure is completely disturbed, and from that reason other symptoms are invisible (Fig. 24).

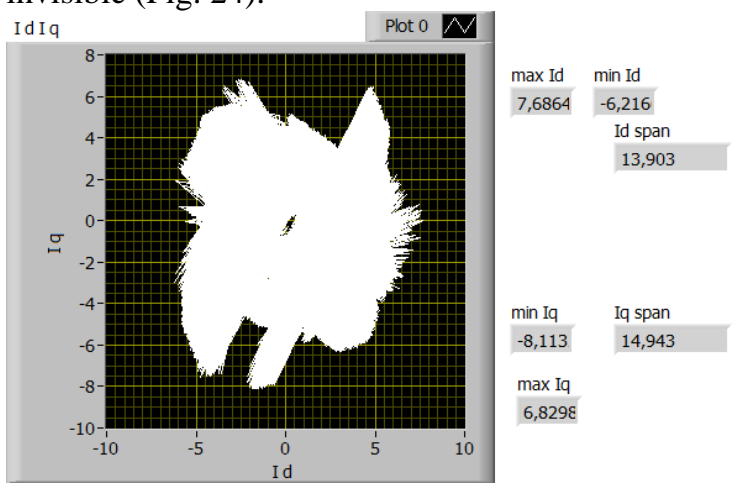

Fig. 24. Lissajous figure- damaged outer ring of the bearing

In both figures: 22 and 24 spans measures were taken, but unfortunately they may not be treated as symptoms of bearing problem. The problems with stator windings are so dominant that the Lissajou figure is to irregular to use it for the purpose of bearings diagnosis.

\subsection{Damaged outer ring of bearing $6303 Z$ (drive side)}

Next experiment assumes that the outer ring of second bearing is damaged. As a first step the characteristic frequencies for this kind of bearing were defined (Table 8).

Table 8. Characteristic frequencies of $6303 Z$ bearing

\begin{tabular}{l|l}
$\begin{array}{l}\text { Bearing- fan side } \\
\text { Number of balls }\end{array}$ & $\mathbf{6 3 0 3 Z}$ \\
$\begin{array}{l}\text { Input parameters } \\
\mathrm{n}_{\mathrm{i}} \text { - Rotational speed of the inner ring }\end{array}$ & $1080 \mathrm{r} / \mathrm{min}$ \\
\hline $\begin{array}{l}\text { Result } \\
\mathrm{f}_{\mathrm{i}} \text { - Rotational frequency of the inner } \\
\text { ring }\end{array}$ & $18,00 \mathrm{~Hz}$ \\
\hline $\begin{array}{l}\mathrm{f}_{\mathrm{e}}-\text { Rotational frequency of the outer } 0,00 \mathrm{~Hz} \\
\text { ring }\end{array}$ & $6,54 \mathrm{~Hz}$ \\
\hline $\mathrm{f}_{\mathrm{c}}-$ Rolling element set \& cage & $30,50 \mathrm{~Hz}$ \\
\hline $\mathrm{f}_{\mathrm{r}}-$ Rolling element about its axis & $80,10 \mathrm{~Hz}$ \\
\hline $\mathrm{f}_{\mathrm{ip}}-$ Point on inner ring & $45,80 \mathrm{~Hz}$ \\
\hline $\mathrm{f}_{\mathrm{ep}}-$ Point on outer ring & $61,00 \mathrm{~Hz}$ \\
\hline $\mathrm{f}_{\mathrm{rp}}-$ Rolling element &
\end{tabular}

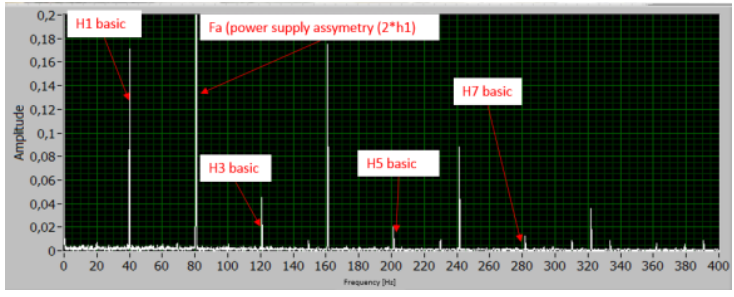

Fig.25. Damaged outer ring of $6303 \mathrm{Z}$ bearing in SEW gear motor

Figure 25 presents the spectrum of Parks's vector taken from the input current. One may observe overheated windings. In both cases, due to damaged windings isolation, problem of bearing could not be identified in spectrum of input current.

\section{SUMMARY}

The paper presents results of diagnosis of two electric induction motors on the basis of electric parameters observation. The main purpose was to analyze the effectiveness of described methods for selected faults or malfunctions which may occur on main drive of industry stamping press.

Presented research was performed on the laboratory stands due to inability of conducting similar active diagnostic experiments directly in industry conditions. Nevertheless, the below mentioned conclusions have been noticed and will be applied in a scaled version of industry diagnostic system.

Performed spectra analysis was done for two types of signals- raw signal and for Extended Park's Vector Approach. The second method gives better results due to the fact that it decreases the influence of basic harmonic, so that it is not dominant anymore and the symptoms are more visible.

Lissajous figures have a huge potential for further analysis of figure pattern. Additionally spans of those figures can become a good basis for identification of particular malfunction.

In both, above methods serious problems with stator windings become dominant and the problems with bearings are the invisible in both current spectrum and park- Clarke Lissajou figure.

Frequency inverter has a huge influence on harmonics that are visible in current signal. Additional harmonics are introduced to the system and it is necessary to be familiar with principle of operation of inverter to identify them. Those, additional harmonics may be also treated as symptoms for deeper analysis of the induction motor. The resonance frequency of output filter covered with harmonic number 23 and amplified its amplitude.

The complete research gave a good overview of components in stator current spectrum that may be expected during diagnosis of induction motor supplied from frequency inverter. The main potential defects that occurred already on industrial application were simulated and the response of 
system was approved. The next step and next phase of complete project will be implementation of diagnosis system in main drive of stamping press line.

\section{REFERENCES}

1. Mazur AG. Electric Motor Drive Installation and Troubleshooting, Troubleshooting Electric/Electronic Systems, Publisher: Amer Technical Pub; 3rd Edition edition 2015

2. Dongdong Z, Ruichi A, Thomas W. Effect of voltage unbalance and distortion on the loss characteristics of three-phase cage induction motor, 2017.

3. Gheitasi A, Motor fault recognition using distributed current signature analysis, School of Engineering, 2013 , interner address

https://openrepository.aut.ac.nz/bitstream/handle/102 92/5280/GheitasiA.pdf?sequence $=3 \&$ is Allowed $=y$

4. Dubravko M. Brief review of motor current signature analysis. 2015: 5(1): 14-26.

5. Mohamed el Hachemi Benbouzid. A review of induction motors signature analysis as a medium for faults detection, IEEE transactions on industrial electronics. 2000; 47(5):984-993.

6. Weinreb K, Duda A, Petryna J, Sułowicz M. Diagnostyka ekscentryczności silnika indukcyjnego w oparciu o pomiar strumienia poosiowego. Maszyny elektryczne. 2015;2:13-20.

7. Salomäki J, Hinkkanen M, Jorma L. Influence of Inverter Output Filter on the Selection of PWM Technique, IEEE, 2006:1052-1057 https://doi.org/10.11.09/ISIE.2006.2957.82

8. Fidali M, Nowoczesne metody diagnozowania napędów elektrycznych. Służby utrzymania ruchu. 2016; 5(61):32-36.

9. William R Finley, Mark M. Hodowanec, Warren G. Holter, An Analytical Approach to Solving Motor Vibration Problems, IEEE, Paper No. PCIC-99-20.

10. ISO 20958:2013 (en) Condition monitoring and diagnostics of machine systems- Electrical signature analysis of three-phase induction motors.

11. SINAMICS V20 Inverter, operating instruction, Siemens 2017

12. LEM HAS 50- Operating instruction, LEM HAS 50, available in Internet: https://www.lem.com/en/product-list?keys=has+50

13. Zarei J, Hassani H, Zuolong W, Reza H, Broken rotor bars detection via Park's vector approach based on ANFIS, IEEE, $23^{\text {rd }}$ (ISIE), 2014.

https://doi.org/10.11.09/isie.2014.6864999

14. EN 61000-2-4 Kompatybilność elektromagnetyczna (EMC) Środowisko - Poziomy kompatybilności dotyczące zaburzeń przewodzonych małej częstotliwości w sieciach zakładów przemysłowych.

15. IEEE 519 Recommended Practices and Requirements for Harmonic Control in Electrical Power Systems.

16. Iorgulescu M, Beloiu R. Vibration and Current Monitoring for Fault's Diagnosis of Induction Motors, Annals of the University of Craiova, Electrical Engineering series. 2008;32.

17. Zhang P. Active thermal protection for induction motors fed by motor control devices, $\mathrm{PhD}$ dissertation, Georgia Institute of Technology. Pinjia Zhang 2010

18. Iorgulescu M. Study relation between fault noise in electric motor, University of Pitesti. 2010; 2(4): 6973.
19. Glinka T. Badania diagnostyczne maszyn elektrycznych w przemyśle. BOBRME Komel, 2002.

20. Swędrowski L. Measuring System for Analysis of Motor Supplying Current for Diagnostic Purposes. International Symposium on Diagnostics for Electric Machines, Power Electronics and Drives Vienna, Austria.

https://doi.org/10.1109/demped.2005.4662505

Received 2019-04-18

Accepted 2019-10-12

Available online 2019-10-16

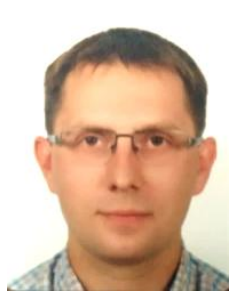

Krzysztof ROCZEK, M.Sc., Eng. Institute of Fundamentals of Machinery Design, Silesian University of Technology. $\mathrm{He}$ received the M.Sc. degree in 2010 on Silesian University of Technology and now he is actual working toward his $\mathrm{PhD}$ thesis. Since 2011 he has been working also as Controls Engineer at press shop in Opel Manufacturing Poland company. His main research interests includes diagnostic with use of electric current and industrial networks.

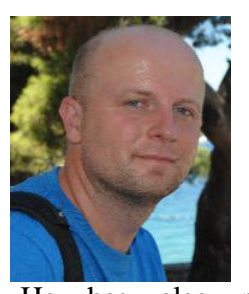

Tomasz ROGALA, PhD Eng., Institute of Fundamentals of Machinery Design, Silesian University of Technology. His main interests focused mainly on: diagnostic knowledge modeling, digital signal processing, application of simulation experiments in technical diagnostics. $\mathrm{He}$ has also research interest in application of computational intelligence methods for different engineering problems. 